\title{
Neformalna naselja v postsocialističnih mestih - dejavniki raznolikosti in vzorci neformalnih naselij
}

$\mathrm{V}$ nekaterih postsocialističnih mestih je nastajanje neformalnih naselij pojav, povezan $\mathrm{z}$ valom urbanizacije $\mathrm{v}$ šestdesetih in sedemdesetih letih prejšnjega stoletja, $\mathrm{v}$ drugih pa s pritokom priseljencev in beguncev v devetdesetih letih. Območja neformalnih naselij nastajajo zaradi različnih dejavnikov: neustreznega prostorskega načrtovanja, zastarele in zapletene zakonodaje, ureditve javne uprave in stanovanjske politike, ki ne zagotavlja cenovno dostopnih stanovanj. Nezakonita gradnja na mestnih območjih, ki je pogosto posledica pomanjkanja jasno oblikovanega sistema lastninskih pravic in mestne revšcine, je resen problem v mnogih mestih, kot so Tirana, Beograd, Tbilisi in Bukarešta. Članek predstavlja tipologijo neformalnih naselij v postsocialističnih mestih in obravnava ekonomske, socialne in okoljske probleme, povezane s tem pojavom. Različne vrste neformalnih naselij in njihov razvoj kažejo na zapletenost vprašanja in potrebo po oblikovanju raznolikih rešitev, ki bi upoštevale razmere danega okolja. Raziskava obravnava odzive politike povezane $s$ tem, med njimi legalizacijo in vključevanje tovrstnih naselij v projekte urbanističnega načrtovanja, zagotavljanje osnovnih socialnovarstvenih storitev (na primer šole in zdravstveni domovi), izgradnjo tehnične infrastrukture (na primer varne ceste, omrežja javnega potniškega prometa, vodovod in kanalizacija) in programe preselitve v socialna stanovanja. Čeprav te rešitve spadajo v okvir različnih politik, je za njihovo učinkovito izvedbo potrebno veliko politične volje ter tudi finančna zavezanost osrednjih in lokalnih ustanov.

Ključne besede: postsocialistična mesta, neformalna naselja, mestna revščina, cenovno dostopna stanovanja, odzivi politike 


\section{Uvod}

V nekaterih postsocialističnih mestih je nastajanje neformalnih naselij pojav, povezan $\mathrm{z}$ valom urbanizacije $\mathrm{v}$ šestdesetih in sedemdesetih letih preǰsnjega stoletja, $\mathrm{v}$ drugih pa s pritokom priseljencev in beguncev v devetdesetih letih. Posamezniki, ki ǐ̌čejo različne ekonomske priložnosti v hitro rastočih postsocialističnih mestih, se pogosto naseljujejo na periurbanih območjih. Ta ad hoc odziv na hitro urbanizacijo se razlikuje od » prve generacije « neformalnih naselij, ki so nastala v socializmu, saj za tovrstna sodobna naselja ni nujno, da imajo značilnosti slumov. Prav nasprotno, na teh območjih živijo tudi meščanske družine in gradnja na pogosto zasebnih zemljiščih je velikokrat kakovostna. Neformalna narava teh gradenj je povezana z neupoštevanjem urbanističnega načrtovanja in/ ali gradbenih dovoljenj. Neformalna naselja nastanejo zaradi različnih dejavnikov: neustreznega prostorskega načrtovanja, zastarele in zapletene zakonodaje in ureditve javne uprave ter neustrezne stanovanjske politike.

Nova neformalna naselja danes pogosto nastanejo zaradi revščine in socialne izključenosti. Rastoča mestna revščina v nekaterih postsocialističnih mestih se kaže $\mathrm{v} \gg$ drugi generaciji « neformalnih naselij, zgoščenih na periurbanih območjih velikih mest in tudi v getih v mestnih središcih. Vojne na Balkanu, ki sta jim sledila begunska kriza in pritok notranje razseljenih oseb, so stanje samo še poslabšale. Nezakonita gradnja na mestnih območjih, ki je pogosto posledica pomanjkanja jasnega sistema lastninskih pravic ali neizvajanja obstoječih urbanističnih predpisov, je resen problem v mnogih mestih, na primer v Tirani, Beogradu, Tbilisiju in Bukarešti.

Članek predstavlja tipologijo neformalnih naselij v postsocialističnih mestih in obravnava soodvisne ekonomske, socialne in okoljske probleme, povezane s tem pojavom. Osredotoča se na postsocialistična mesta Jugovzhodne Evrope, v katerih različne vrste neformalnih naselij in njihov razvoj kažejo na zapletenost vprašanja in potrebo po oblikovanju raznolikih rešitev, ki bi upoštevale razmere danega okolja. Raziskava obravnava odzive politike, povezane s tem, med njimi legalizacijo in vključevanje tovrstnih naselij v projekte urbanističnega načrtovanja, zagotavljanje osnovnih socialnovarstvenih storitev (na primer šole in zdravstveni domovi), izgradnjo tehnične infrastrukture (na primer varne ceste, omrežja javnega potniškega prometa, vodovod in kanalizacija) in programe preselitve v socialna stanovanja. Čeprav te rešitve spadajo v okvir različnih politik, je za njihovo učinkovito izvedbo potrebno veliko politične volje ter tudi finančna zaveza osrednjih in lokalnih ustanov. Osnovna teza članka je, da je za izboljšanje stanovanjskih razmer revnega mestnega prebivalstva treba preseči konvencionalno načrtovanje in rešitve, povezane $\mathrm{z}$ lastninsko pravico na zemljišču oziroma z njegovo prijavo. Sistemski problemi tržno usmerjene stanovanjske ponudbe, vse večje neenakosti v stanovanjskih razmerah in posledično nastajanje neformalnih naselij samo poslabšujejo položaj revnega prebivalstva.

\section{Neformalna bivališča in naselja $\mathbf{v}$ Jugovzhodni Evropi}

Neformalna bivališča v postsocialistični Evropi se v okviru neformalnih naselij pogosto obravnavajo ob upoštevanju dejstva, da ta pojav zelo narašča in $\mathrm{v}$ mnogih državah že zaseda večji del mestne pokrajine. Dunajska deklaracija o nacionalni regionalni politiki in programih neformalnih naselij v Jugovzhodni Evropi (ang. The Vienna Declaration on National Regional Policy and Programmes on Informal Settlements in South Eastern Europe) neformalna naselja opredeljuje tako: »Človeška naselja, ki zaradi različnih razlogov ne izpolnjujejo pogojev za priznanje zakonske pravice (in so bila zgrajena brez upoštevanja formalnih postopkov za pridobitev in prenos lastništva ter gradbenih in urbanističnih predpisov), obstajajo v svoji državi in ovirajo njen gospodarski razvoj. Čeprav obstajajo pri oblikah teh naselij pomembne regionalne razlike, so zanje značilni predvsem neformalno lastništvo oziroma negotove lastninske pravice in neustrezen dostop do osnovnih storitev, kot so socialna in fizična infrastruktura ter stanovanjsko financiranje. « (Ministrska konferenca o neformalnih naseljih $\mathrm{v}$ Jugovzhodni Evropi, 2004: 1.)

Čeprav obstaja več različnih oblik neformalnih bivalǐ̌č, mnoge opredelitve kot njihovo glavno značilnost poudarjajo neformalno naravo naselitve in neupoštevanje načrtov rabe zemljiščc. $\mathrm{K}$ značilnostim neformalnih bivališč prištevamo tudi te (Program Združenih narodov za naselja, ang. United Nations Human Settlements Programme, v nadaljevanju: UN-HABITAT, 2003; Payne in Majale, 2004):

- negotove lastninske pravice;

- pomanjkanje osnovnih storitev;

- kršenje mestnih predpisov;

- gradnja na zemljiřču, ki ni v lasti graditelja;

- neustrezen dostop do osnovnih javnih storitev;

- slabe bivalne razmere, nezakonite in neprimerne gradnje;

- nezakonita parcelacija naselja;

- revšcina in socialna izključenost ter

- nezdrave in nevarne življenjske razmere.

Razprave v okviru stanovanjske politike se vztrajno osredotočajo na neformalno in nezakonito naravo teh naselij. Nezakonitost se nanaša predvsem na neupoštevanje načrtovalskih in gradbenih norm in zlasti na vprašanja lastništva. Stanovalci neformalnih naselij pogosto nimajo lastninske pravice na zemljišču ali objektu in jim zato grozi prisilna izselitev. Njihovo ranljivost dodatno povečujejo slabe bivalne razmere in omejen dostop do storitev, prevoza, izobraževanja in zdravstvene 
oskrbe, ki so posledica fizične in pravne marginalizacije z vidika formalne mestne sestave. Taka smer razvoja je značilna za Albanijo, Makedonijo, Hrvaško, Črno goro in Srbijo.

Neformalna naselja pogosto enačimo s slumi, kar ni pravilno. $\mathrm{V}$ mnogih predelih res izražajo revščino, izključenost in stisko, vendar pa to ne velja vedno. Čeprav mnoga neformalna naselja nimajo zagotovljenih lastninskih pravic, sta lahko gradnja in infrastruktura vseeno kakovostni. $\mathrm{V}$ nekaterih primerih so razmeroma bogati prebivalci in špekulativni izvajalci pri gradnji preprosto kršili gradbene zakone in predpise namenske rabe zemljiščc.

\section{Prostorske pojavne oblike in proces oblikovanja neformalnih naselij}

Zgodovina razvoja neformalnih naselij v Jugovzhodni Evropi je raznolika in se precej razlikuje glede na življenjski standard (od slumov do luksuznih stanovanj), lokacijo (od predmestij do mestnih središč in zavarovanih območij) in velikost (od nekaj manjših enot do naselij z več kot 50.000 prebivalci). K nezakoniti in nedosledni gradnji v večjih mestih je med drugim prispeval tudi val migrantov $s$ podeželja ter pritok beguncev in notranje razseljenih oseb na ta območja. Poleg reševanja nujnih bivalnih potreb so mnogi nezakonite naložbe v nepremičnine izkoristili kot »zaščito « pred nestabilnostjo in hiperinflacijo. Vrste neformalnih naselij lahko določamo na podlagi številnih dejavnikov, kot so na primer velikost, lokacija, značilnosti prebivalcev in prostorska organizacija. Število mogočih pojavnih oblik je veliko, v literaturi pa so navedene te glavne vrste:

1. ilegalna naselja (ang. squatter settlements) na javnih ali zasebnih zemljiščih,

2. naselja za begunce in ranljive skupine,

3. ilegalna naselja z izboljšano infrastrukturo,

4. ilegalne parcelacije na zasebnih ali javnih zemljiščih v pred mestjih.

\subsection{Ilegalna naselja}

Ena najtrdovratnejših oblik neformalnih naselij so ilegalna naselja, zgrajena na zemljiščih, ki niso v lasti graditeljev. V postsocialističnih mestih bivše Jugoslavije so bila ta naselja zgrajena v sedemdesetih in osemdesetih letih prejšnjega stoletja. V Albaniji so novejša, saj so nastala v začetku devetdesetih let. Ta naselja so večinoma posledica hitrega priseljevanja $\mathrm{v}$ mesta zaradi migracij in sprememb v mestnem gospodarstvu, hkrati pa so nastala zaradi postopnega procesa naseljevanja in pospešenega širjenja mest. Nahajajo se na javnih ali zasebnih zemljiščih periurbanih območij, razširila pa so se do te mere, da so postala že prave samostojne občine, $v$ katerih živi več sto tisoč ljudi. Čeprav so morda sprva nastajala predvsem zato,

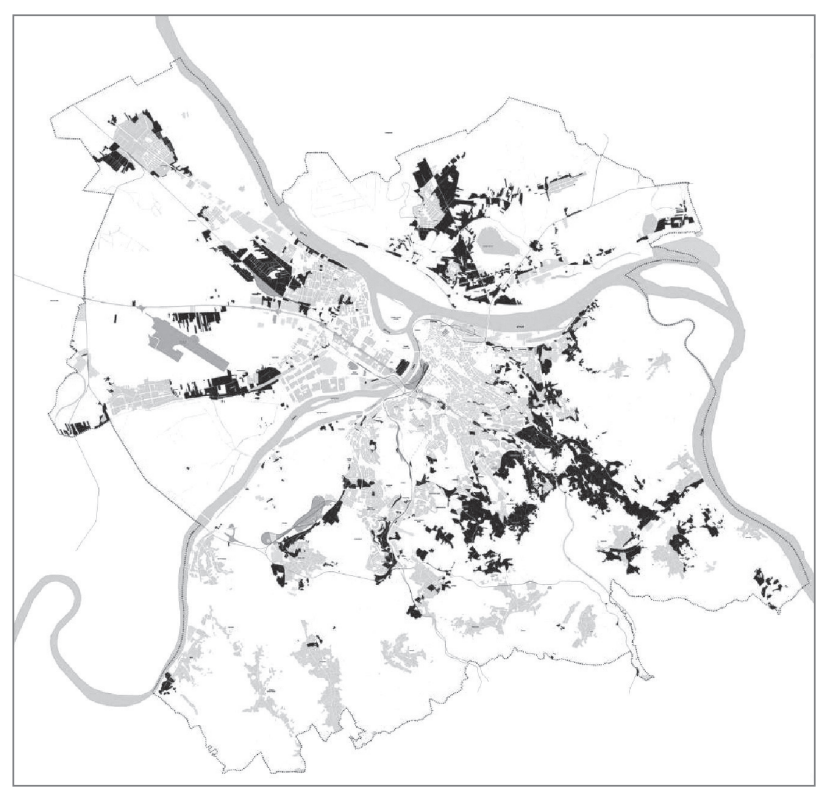

Slika 1: Neformalna naselja v Beogradu (vir: UN-HABITAT, 2006)

ker so oblasti zamižale na eno oko, zlasti med priseljevanjem priseljencev v mesta takoj po zlomu socializma, je danes njihov obseg resen problem. V Albaniji na primer v neformalnih naseljih živi do $25 \%$ vseh prebivalcev večjih mest, neformalna naselja pa pomenijo $40 \%$ vseh pozidanih površin v mestu. $\mathrm{V}$ Makedoniji živi v takih naseljih $11 \%$ prebivalcev štirinajstih največjih mest. V Beogradu neformalna naselja kazijo mestno podobo in zavzemajo do $40 \%$ stanovanjskih površin (slika 1).

Poleg obsežnih periurbanih ilegalnih naselij, opisanih zgoraj, obstaja tudi veliko drugih primerov neformalnih bivališč, ki so ilegalno zgrajena pod mostovi in nadvozi ter na prostih parcelah v bližini industrijskih con, železniških postaj, strmih rečnih bregov in odlagališč. Ta zemljišča, javna ali zasebna, niso stabilna in niso primerna za mestno gradnjo, hkrati pa nimajo dostopa do osnovne infrastrukture in storitev. Marginalna ilegalna naselja so pogosto zasilna in zgrajena iz odpadnih materialov (slika 2), njihovim prebivalcem pa pogosto grozi

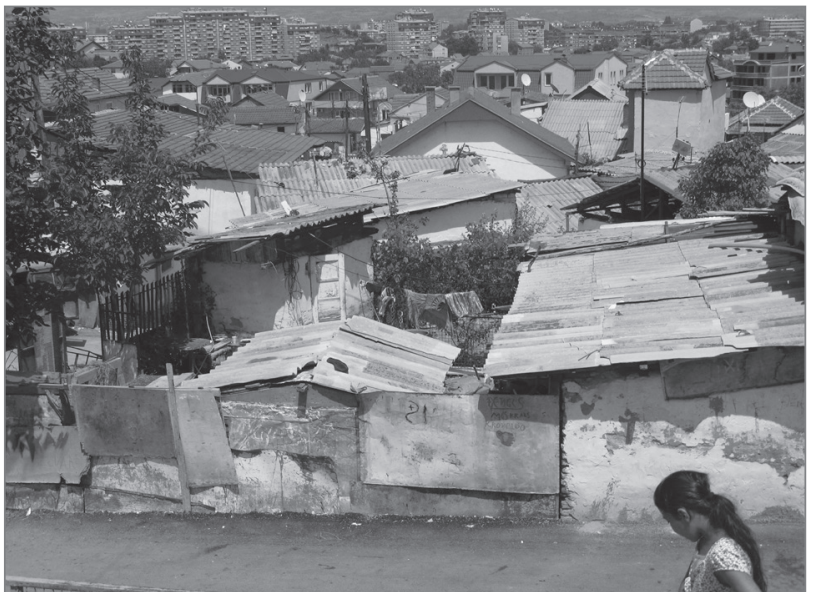

Slika 2: Slumi in neformalna naselja v Skopju (foto: Sasha Tsenkova) 
prisilna izselitev ali rušenje njihovih bivališč. Lokacije naselij in razmere v njih se močno razlikujejo, treba pa je opozoriti na pogosto izključenost prebivalcev, ki živijo v njih. Najbolj znan primer so romske skupnosti v Srbiji, Bolgariji in Romuniji, ki živijo v mahalah, četrtih, ki izvirajo iz devetnajstega stoletja (beograjski urbanistični inštitut, 2003a; Slaev, 2007).

\subsection{Naselja za ranljive skupine}

Neformalna naselja, ki so jih v tej regiji pred kratkim zgradili begunci in notranje razseljene osebe, so pogosto podobna ilegalnim naseljem, opisanim zgoraj, nekatera pa so bila zgrajena z dovoljenjem države ali občine za začasno in hitro reševanje kriznih okoliščin, kot so bili na primer vojaški spopadi v devetdesetih letih prejšnjega stoletja. Čeprav so bila ta naselja zgrajena še pred kratkim, so življenjske razmere v njih izredno slabe. Pogosto gre za barake, zgrajene iz odpadnih materialov, večjih kosov plastike, kartona in ostankov gradbenih materialov. V nekaterih naj bi ljudje prebivali le začasno, dokler ne bi zanje uredili preselitve $\mathrm{v}$ begunska taborišča in zbirne centre, vendar so na koncu postala dolgotrajnejša bivališča, ki so povrhu privabljala še več ljudi. Ti slumi imajo omejen dostop do osnovnih storitev in se običajno nahajajo na mestnem obrobju, na zemljiščih slabše kakovosti ali v bližini begunskih zbirnih centrov (center za spremljanje notranjega razseljevanja, 2007).

\subsection{Ilegalna naselja z izboljšano infrastrukturo}

Obstajajo različni vzorci neformalnih naselij, zgodovinske okolišcine, povezane $\mathrm{z}$ njihovim nastankom, pa so prav tako raznolike. Nekatera naselja so bila na začetku sedemdesetih let prejšnjega stoletja ilegalno zgrajena na periurbanih območjih, nato pa so se preoblikovala v uglednejše soseske. Skopje, na primer, ima 27 sosesk, ki so bile ilegalno zgrajene po potresu $\mathrm{v}$ šestdesetih letih prejšnjega stoletja. Pravni status teh naselij je različen: večina je bila sprva zgrajena ilegalno, sčasoma pa so nekatera pridobila zakonske lastninske pravice (na primer v Srbiji in Makedoniji).

V nekaterih primerih se je dejanska zakonitost uveljavljala na podlagi dejstva, da teh naselij niso porušili in da so $\mathrm{v}$ njih zagotovili vsaj del najosnovnejše infrastrukture (na primer vodovod, elektrika in kanalizacija). Obstajajo primeri, v katerih so taka naselja vključili v mestne načrte, med njimi tudi beograjsko sosesko Kaluđerico (ponazoritev 1). To je nekaterim boljšim naseljem omogočilo hiter razvoj, saj so prebivalci v svoje domove vlagali in s tem izboljševali lokalno okolje. $\mathrm{Na}$ selja $\mathrm{z}$ izboljšano infrastrukturo so pogosto živahne soseske $s$ cvetočim najemniškim in nepremičninskim trgom.

Ponazoritev 1: Neformalna naselja z izboljšano infrastrukturo: Kaluđerica

Kaluđerica je eno najhitreje rastočih naselij v Srbiji in najbrž največja vas na Balkanu. Nahaja se samo osem kilometrov od Beograda in že od osemdesetih let prejšnjega stoletja hitro raste skupaj z mestom. V osemdesetih je njeno prebivalstvo štelo 12.000 ljudi, danes pa število prebivalstva ocenjujejo na 50.000; povečanje je mogoče pripisati tudi beguncem iz Bosne in Hercegovine, s Hrvaške in Kosova. Čeprav je Kaluđerica uradno podeželsko naselje, ki je petkrat večje od občinskega glavnega mesta Grocke, gre pravzaprav za neformalno zgrajeno naselje. Večina objektov nima gradbenega dovoljenja, vendar imajo stanovalci zemljišča v lasti, nekatera pa so celo vpisana v zemljiško knjigo. Sčasoma so se prebivalci z odgovornimi pogodili za priključitev na infrastrukturo, zgradili ceste in uredili dostop do storitev beograjskega javnega potniškega prometa in Telekoma Srbije.

Vir: beograjski urbanistični inštitut (2003b)

\subsection{Ilegalne parcelacije}

Pri nekaterih neformalnih naseljih v obravnavani regiji ne gre za stanovanjska območja nižje kakovosti s slabim dostopom do storitev. Veliko stanovalcev ima na zemljišču lastninsko pravico, vendar so objekti zgrajeni brez gradbenega dovoljenja. Nedovoljene gradnje in ilegalne parcelacije so razširjene na obrobju mest Jugovzhodne Evrope. Pri ilegalni parcelaciji zakoniti lastnik kmetijskega zemljišča zemljišče razdeli na parcele in jih proda kupcem, ki na njih nato gradijo svoje domove $^{[1]}$. Lastniki tako periurbana zemljišča brez vsakršnih uradnih dovoljenj spreminjajo v urbana. V nekaterih državah gradbena podjetja ta proces izkoriščajo za gradnjo stanovanj za meščanske družine. $\mathrm{V}$ ponazoritvi 2 je prikazan tak proces v Romuniji. Naselja so ilegalna, ker kršijo prostorske predpise, imajo slabo infrastrukturo, parcelacija zemljišč pa pogosto ne upošteva urbanističnih standardov za služnostno pot, dostop do cest in zagotavljanje javnih prostorov.

Ponazoritev 2: Ilegalna parcelacija kmetijskih zemljišč, ki so bila spremenjena v predmestno stanovanjsko naselje: Piteşti

Do ilegalne parcelacije v romunskem mestu Piteşti je prišlo takoj po denacionalizaciji kmetijskih zemljišč na obrobju mesta. Novi lastniki so takoj razdelili 4,1 hektarja zemlje, ki se nahaja poleg stanovanjskega naselja s 5.000 stanovanji in zaščitenega gozda. Novi lastniki, ki so večinoma stanovali v večstanovanjskih zgradbah $v$ tem naselju, so si prisvojili več kot 300 parcel in na njih začeli graditi svoje sanjske domove. Danes lahko tukaj najdemo že skoraj 150 novih objektov na različnih stopnjah gradnje, ki izražajo mešanico mestnega in podeželskega življenjskega sloga prebivalcev naselja. V nekaj letih je bilo to območje zaradi hitro odobrenih prostorskih načrtov vključeno v občino, zaradi česar so se povišale cene zemljišč. Stanovalci so uredili zasebne ceste, ki zavzemajo samo $9 \%$ zemljišč, na podlagi povrnjenih stroškov priključili svoje parcele na električno omrežje ter uredili oskrbo z vodo iz omrežja in greznico. Uspeli so celo zbrati sredstva za oskrbo s plinom, še vedno pa uporabljajo javno socialno infrastrukturo $v$ sosednjem naselju.

Vir: Soaita (2007)

Druga oblika ilegalne parcelacije v regiji so neformalna naselja na rekreacijskih in obalnih območjih. Ta problem je značilen 
predvsem za Albanijo, Hrvaško, Črno goro in do neke mere tudi za Bolgarijo ter je največkrat posledica želje po dobičku in špekulativnem vlaganju $\mathrm{v}$ rastoči trg počitniških hišic kot potrebe po stanovanjih. Lahko gre za redko pozidana stanovanjska naselja na podeželju s kakovostno zgrajenimi objekti, vendar slabim dostopom do storitev. Včasih se razširijo na rekreacijska območja, ki niso uradno določena za gradnjo, to pa postane velik problem, ko se naselje začne širiti in zgoščati.

\subsection{Lokacija in velikost}

Neformalna naselja se običajno zgoščajo na dveh obsežnih lokacijah: $\mathrm{v}$ središču mesta in na periurbanih območjih. Lokacije v središču mesta so pogosto starejše in uglednejše, nahajajo pa se blizu starega dela mesta ali industrijskih con. Stanovalci imajo dober dostop do delovnih mest, vendar pogosto živijo v slabih stanovanjskih razmerah na območjih, ki so izpostavljena okoljskim in zdravstvenim tveganjem. Ta območja običajno niso primerna za razvoj naselij. V večini primerov se neformalna naselja, zlasti obsežnejša, zgoščajo na obrobju mest, ker so tam zemljišča običajno cenejša. Lahko gre za ilegalna naselja na javnih zemljiščih ali nezakonite parcelacije zunaj mestnih/ občinskih meja. Kakovost in razmere v teh stanovanjih so običajno boljše, ilegalna priključitev na obstoječo infrastrukturo pa včasih zagotovi prepotrebno dobavo elektrike in vode. Stanovalci teh naselij se razmeroma učinkovito upirajo preselitvi ali rušenju svojih domov. V preglednici 1 so predstavljene glavne oblike neformalnih naselij s podatki o lokaciji in kakovosti.

\section{Ekonomska, socialna in okoljska vprašanja, povezana z neformalnimi naselji}

Obravnavanje težav, povezanih z neformalnimi naselji, zahteva širše razumevanje silnic, ki prispevajo k povečevanju njihovega števila, pa tudi upoštevanje soodvisnih ekonomskih, socialnih in okoljskih vprašanj. Države v preučevani regiji, za katere je značilna rast neformalnih naselij, se soočajo z enakimi sistemskimi težavami, povezanimi s pomanjkanjem cenovno dostopnih stanovanj, z neučinkovitimi sistemi načrtovanja in upravljanja z zemljišči ter naraščajočo mestno revščino. Običajno je v tem procesu skupni učinek ekonomskega preoblikovanja in vojnih spopadov povzročil nenadno pospešeno migracijo in širjenje neformalnih naselij. Državna in lokalna raven večinoma nista bili pripravljeni na obremenitve zemljiščc, stanovanj in storitev. Petnajst let po koncu vojne neformalna naselja pokrivajo velika območja periurbanih zemljišč, v njih pa živijo tako socialno ranljive skupine kot razmeroma bogati migranti. Kot navaja Bjoern Gabriel (2007: 5), » to ni preprosto ,urbanistični problem, ampak bolj zapleten in težko rešljiv problem, ki lahko ogrozi dolgoročni trajnostni razvoj mestnih skupnosti, če ga ne bomo hitro in učinkovito rešili«.

$\mathrm{V}$ okviru ekonomske in politične liberalizacije, ki jo spremlja zgoščevanje revnih in neprivilegiranih skupin $\mathrm{v}$ mestih, je treba reševati eksplozivno rast neformalnih naselij na periurbanih območjih. Obstaja splošno prepričanje, da je reševanje »urbanega problema « neformalnih naselij povezano z mrežo izboljšanega dostopa do cenovno ugodnih zemljišč in stanovanj in razvojem učinkovitih načrtovalskih ureditev. Raziskava Svetovne banke (2007) o neformalnih naseljih v tranzicijskih gospodarstvih v zgoščeni obliki povzema to problematiko (ponazoritev 3).

Ponazoritev 3: Omejitve na področju načrtovanja in upravljanja z zemljišči

V okviru analitičnega in projektnega dela Svetovne banke $v$ številnih državah obravnavane regije so bili ugotovljeni ti skupni dejavniki, ki vplivajo na neformalna naselja:

- Neobstoj novejšega »ureditvenega načrta« (načrta rabe zemljišč) in sprejetih lokalnih predpisov o rabi zemljišč. Načrti so lahko zastareli ali niso popolni. Številne podatke, kot so prepreke, širina glavnih cest, količnik med bruto tlorisno površino objekta nad terenom in površino gradbene parcele ter maksimalna višina, je treba določiti za vsak projekt posebej. To vodi v višje stroške gradnje, saj povzroča daljše zamude in ustvarja vtis samovoljnosti, hkrati pa je videti kot priložnost za korupcijo. Če je proces dolgotrajen in ni jasen, veliko državljanov nima ustreznega znanja, časa in sredstev, da bi sledili postopkom.

- Pomanjkanje programov za gradnjo primarne infrastrukture, ki bi jih financirala občina. Brez posodobljenih načrtov infrastrukturnega omrežja morajo investitorji sami graditi in financirati povezave med svojimi enotami in obstoječim infrastrukturnim omrežjem ali pa širitev tega omrežja. To vodi v razdrobljenost sistema, zaradi česar je njegovo vzdrževanje negospodarno in drago. Posamezniki morda sploh nimajo dostopa do infrastrukture ali pa »kupujejo« nezakonite priključke.

- Težavnost uradnega in zakonitega nakupa komunalno neopremljenih zemljišč za gradnjo. Večino nezazidanih zemljišč

Preglednica 1: Oblike neformalnih naselij v Jugovzhodni Evropi

\begin{tabular}{lcccc}
\hline & $\begin{array}{c}\text { Središče } \\
\text { mesta }\end{array}$ & $\begin{array}{c}\text { Periurbano } \\
\text { območje }\end{array}$ & $\begin{array}{c}\text { Slabe stanovanjske } \\
\text { razmere/slumi }\end{array}$ & $\begin{array}{c}\text { Razmeroma } \\
\text { dobra kakovost }\end{array}$ \\
\hline ilegalna naselja na javnih ali zasebnih zemljiščih & $\mathrm{x}$ & $\mathrm{x}$ & $\mathrm{x}$ & $\mathrm{x}$ \\
\hline naselja za begunce in ranljive skupine & $\mathrm{x}$ & & & $\mathrm{x}$ \\
\hline izboljšana ilegalna naselja & $\mathrm{x}$ & $\mathrm{x}$ & $\mathrm{x}$ \\
\hline nezakonite parcelacije na zasebnih ali javnih zemljiščih & & $\mathrm{x}$ & & $\mathrm{x}$ \\
\hline
\end{tabular}


po mestih bremenijo lastniški spori in restitucijski zahtevki ali pa so v državni lasti in se zato na trgu ne prodajajo. Investitorje in posameznike pri iskanju razpoložljivih zemljišč ovirajo tudi nepopolni podatki ter veliko število odgovornih agencij in ministrstev.

- Visoki transakcijski stroški v formalnem sektorju, zapleteni procesi in neodzivnost ustanov. V mnogih državah obiskovanje številnih uradov za ureditev potrebnega dovoljenja za uradno izgradnjo in prijavo stavbe zahteva veliko časa in denarja. Dolgotrajni in nepregledni postopki lahko spet "spodbudijo» neformalni sektor, $\mathrm{k}$ čemur veliko pripomore tudi nedosledno izvajanje predpisov s strani pristojnih agencij.

Vir: Svetovna banka (2007: 3)

Poleg omejitev, ki so posledica neučinkovitih načrtovalskih ureditev ter sistemov prijave in upravljanja zemljišč, so stanovanjski sistemi v Jugovzhodni Evropi žrtev neravnovesij, ki jih povzročajo pomanjkanje novih najemniških priložnosti (javnih ali zasebnih) za gospodinjstva z nižjimi prihodki, vrtoglave cene mestnih zemljišč in stanovanj na območjih hitre rasti in omejena podpora ranljivim skupinam (na primer starejši ljudje, razseljeni prebivalci, manjšine in socialno ogrožene skupine) pri dostopanju do stanovanj zadovoljive kakovosti. Zato ni presenetljivo, da na nekaterih hitro rastočih mestnih območjih delež socialno ogroženih prebivalcev, ki živijo v slabih stanovanjskih razmerah, narašča in da si ti prebivalci stanovanja uredijo popolnoma neformalno ali pa s pomočjo neformalnih izvajalcev, ki delujejo zunaj zakonitega urbanističnega okvira.

\subsection{Ekonomska vprašanja}

Raziskave potrjujejo, da se rast »neformalnih mest « v večini držav v obravnavani regiji vse bolj sprejema, vendar pa se pri tem ekonomska in socialna vprašanja večinoma podcenjujejo (Gabriel, 2007; Tsenkova, 2008). Le redko priznamo, da je hitra rast »neformalnih mest « pravzaprav največji ekonomski problem na lokalni in mestni ravni.

Z ekonomskega vidika neformalna naselja zahtevajo visoke javne in zasebne naložbe, ki ostajajo zunaj formalnih ekonomskih in naložbenih krogov (De Soto, 2003). Poleg tega so povezana z visokimi javnimi stroški, tako eksplicitnimi kot implicitnimi. Prebivalci teh naselij si pogosto prisvojijo javna zemljišča, pri čemer breme stroškov preložijo na lokalno raven in javne ustanove. Zemljišča, ki so pogosto neenakomerno pozidana $\mathrm{z}$ enodružinskimi hišami, so slabo izkoriščena, saj je zanje značilna razpršena gradnja. Neformalna naselja vplivajo tudi na državno upravljanje in načrtovanje rabe zemljiščc, saj ta naselja nezakonito zasedajo parke, nekdanje industrijske cone, ki niso varne za stanovanjsko gradnjo, ter zemljišča, ki bi se lahko uporabila $\mathrm{v}$ produktivnejše komercialne in socialne namene. Neformalna naselja dolgoročno ovirajo urejen razvoj in rast mesta, storitvene potrebe in splošen nepremičninski potencial. Prebivalci neformalnih naselij ne plačujejo davka na nepremičnine in se pogosto nezakonito priključijo na obstoječo infrastrukturo, zaradi česar zmanjšujejo dohodek, $s$ katerim država zagotavlja osnovne storitve.

Obenem so neformalna stanovanja pomemben del neformalne ekonomije in nepremičninskega trga. Stanovanja in zemljišča na teh območjih se prodajajo brez sodelovanja nepremičninskih agencij, prijave v zemljiško knjigo in zahtevanega plačevanja državnih davkov in pristojbin. Čeprav so zaradi tega stanovanja cenovno dostopnejša in transakcijski stroški nižji, nanje ni mogoče vzeti hipoteke ali jih uporabiti kot varščino za druge poslovne namene (De Soto, 2003). Za mnoge prebivalce je to njihovo največje premoženje (slika 3), vendar so brez lastninske pravice $\mathrm{v}$ nenehni nevarnosti, da bodo svojo naložbo izgubili ali da bo postala »mrtvi kapital«, zlasti zaradi okoljskih tveganj (na primer poplave, zemeljski plazovi ali potresi) ali sodno odrejenega rušenja.

Neformalna naselja povzročajo vladam posameznih držav visoke politične in ekonomske stroške, zlasti pri prisilnih izselitvah, legalizaciji in preselitvah. Prizadevanja za dokumentiranje obsega neformalnih naselij in usmerjanje dodatnih institucionalnih zmogljivosti za vključitev teh naselij v načrtovano mestno območje so izjemno draga. Poleg tega se morajo lokalna raven države in javne ustanove ukvarjati s prijavami zemljišč in nepremičnin, $\mathrm{z}$ reševanjem sporov, $\mathrm{v}$ nekaterih primerih $\mathrm{pa}$ tudi z odškodninami za zasebne lastnike. Ker visokih stroškov niso zmožni obvladati, pred »neformalnimi mesti« pogosto zamižijo.

\subsection{Socialna vprašanja}

Raznolike prostorske oblike neformalnih naselij v obravnavani regiji so povezane $\mathrm{z}$ mnogimi različnimi socialnimi vidiki te problematike, kljub temu pa obstaja več pomembnih vprašanj, ki so skupna vsem državam. Prvič, prebivalci neformalnih naselij so pogosto revni in socialno ogroženi posamezniki, podvrženi nezaposlenosti, socialnim stiskam in negotovim lastninskim pravicam (Leckie, 2002; Organizacija za varnost in sodelovanje v Evropi, v nadaljevanju: OVSE, 2006). Drugič, podatki kažejo, da demografske pritiske notranje razseljenih in ranljivih skupin, kot so na primer Romi, rešujejo prav neformalna naselja (Razvojna banka Sveta Evrope in Svetovna banka, 2004). S pomočjo raziskave med prebivalci neformalnih naselij v Beogradu so ugotovili, da mlade družine z nezadostnimi prihodki za pridobitev formalnih stanovanj pomenijo $35 \%$ vseh prebivalcev; s $23 \%$ jim sledijo begunci, z $18 \%$ pa Romi (ministrstvo za kapitalske naložbe državne skupnosti Srbije in Črne gore, 2004). Brez finančnih sredstev in zanesljive zaposlitve so se mnoge notranje razseljene osebe in begunci, ki so se priselili v Beograd, da bi tam začeli novo življenje, zatekli v neformalna naselja. 


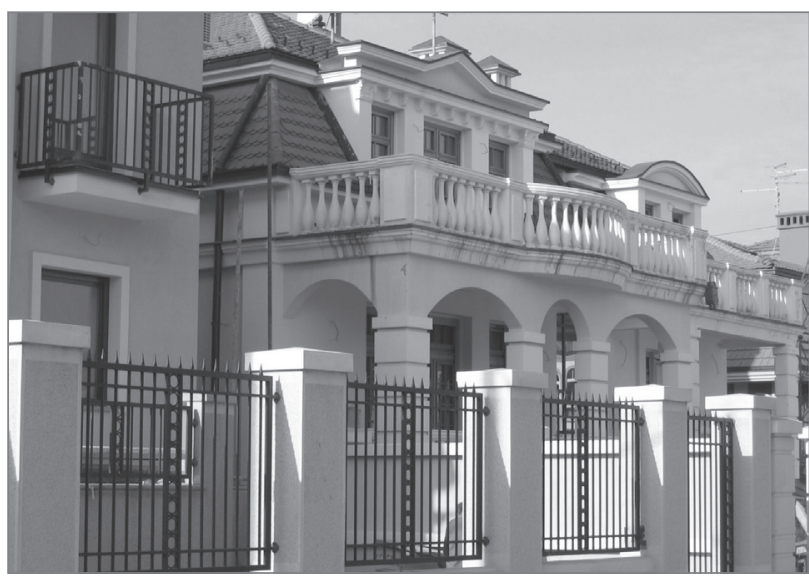

Slika 3: Nova neformalna naselja v Beogradu (foto: Sasha Tsenkova)

Zaradi hitrih sprememb v lokalnem gospodarstvu in vojn se je v državah, kot so Črna gora, Albanija, Kosovo ter Bosna in Hercegovina, več sto tisoč razmeroma revnih migrantov in notranje razseljenih oseb priselilo v večja mesta. Prišleki so se naselili na periurbanih območjih, kjer gradijo hiše na komunalno neopremljenih zemljiščih, pri čemer nezakonito naseljujejo zasebna ali javna zemljišča. $\mathrm{V}$ večini primerov se revščina in pomanjkanje kažeta v kakovosti objektov in tudi v vzorcu mestne gradnje, za katerega so značilne slabe stanovanjske razmere brez kakršne koli socialne ali tehnične infrastrukture (slika 4). Primer iz Kamze ponazarja nekatere od teh problemov v novozgrajenih soseskah (ponazoritev 4).

Ponazoritev 4: Zagotavljanje socialne in komunalne infrastrukture v Kamzi

Občina Kamza je neformalno naselje $v$ Tirani, $v$ katerem je več kot $90 \%$ vseh bivališč zgrajenih nezakonito. $V$ začetku devetdesetih let prejšnjega stoletja je bilo to predvsem kmetijsko zemljišče, danes pa tu živi že približno 60.000 ljudi. Prebivalci so se sem priselili iz severovzhodnih regij Albanije $z$ upanjem na boljše življenje in dobre priložnosti. Polovica ljudi ni zaposlena in polovica vseh gospodinjstev živi pod pragom revščine. Povprečno stanovanje pokriva $119 \mathrm{~m}^{2}$, kar je dvakrat več od povprečja v Tirani. Stanovanja se sprva gradijo v obliki kolib, potem ko ljudje pridobijo dodatna sredstva, pa jih dograjujejo in izboljšujejo. Čeprav so načrtovalska prizadevanja in delo nevladnih organizacij, kot je Co-PLAN, povečala samozavest prebivalcev in omogočila naložbe v vrednosti 110 milijonov USD, zemljišč za gradnjo socialne infrastrukture primanjkuje.

Vir: Besnik idr. (2003)

Poleg slabega dostopa do šol in socialnovarstvenih storitev prebivalci periurbanih območij običajno nimajo lastninske pravice na zemljišč in jim tako grozi prisilna izselitev. Kljub temu obstajajo v obravnavani regiji tudi primeri, $\mathrm{v}$ katerih navedeno ne velja - na primer v starejših naseljih v Srbiji, Makedoniji in Črni gori -, vendar tudi v teh primerih pomanjkanje socialne infrastrukture (šole, zdravniške ambulante in socialne službe) povzroča prostorsko obliko socialne izključenosti.

\subsection{Okoljska vprašanja}

V večini primerov so okoljska vprašanja v neformalnih naseljih povezana s slabo osnovno infrastrukturo. Celo bogatejši prebivalci starejših, izboljšanih naselij nimajo dostopa do čiste vode, primernih cest, javnega prometa in zanesljive dobave elektrike. Položaj ima neposredne posledice za prebivalce, polega tega pa negativno vpliva tudi na kakovost življenja na formalnih območjih mesta, kjer komunalne odplake in dolvodno onesnaževanje kot posledica neposrednega izlivanja odpadne vode in fekalij v reke povzročajo resna okoljska tveganja.

Neurejena infrastruktura v neformalnih naseljih je velik problem. Nezakonita priključitev na infrastrukturo je edini način pridobivanja dostopa do osnovnih storitev, vendar ni zanesljiva in učinkovita. Nezakonita priključitev znižuje učinkovitost gospodarskih javnih služb in zakonite uporabnike izpostavlja pogostim izpadom elektrike in vode. Ker večina prebivalcev neformalnih naselij ne plačuje polne cene za uporabo infrastrukture, ni dovolj dohodkov za pokrivanje naraščajočih zahtev za izboljšanje in širitev infrastrukture. $V$ neformalnih naseljih $\mathrm{v}$ Tirani in Beogradu so velike razlike v dostopu do najosnovnejših storitev $\mathrm{v}$ primerjavi $s$ povprečjem, ki velja za mesto in celotno državo (preglednica 2). V neformalnih naseljih v Tirani so osnovne storitve veliko bližje državnemu povprečju kot v Beogradu. Romska naselja v Beogradu so veliko bolj prikrajšana: samo četrtina stanovanj ima dostop do kanalizacije in samo polovica do vodovodnega omrežja.

Poleg pomanjkanja infrastrukture so nekatera naselja neposredno izpostavljena okoljskim tveganjem, povezanim z zemeljskimi plazovi, $s$ poplavami, z neustreznim odvodnjavanjem in onesnaževanjem okolja (Vucksanovic, 2007). Vse to povzroča zdravstvena tveganja za tamkajšnje prebivalce. Širjenje neformalnih naselij prispeva k okoljski degradaciji na več ravneh:

- erozija kot posledica netlakovanih cestišč brez urejenega odvodnjavanja;

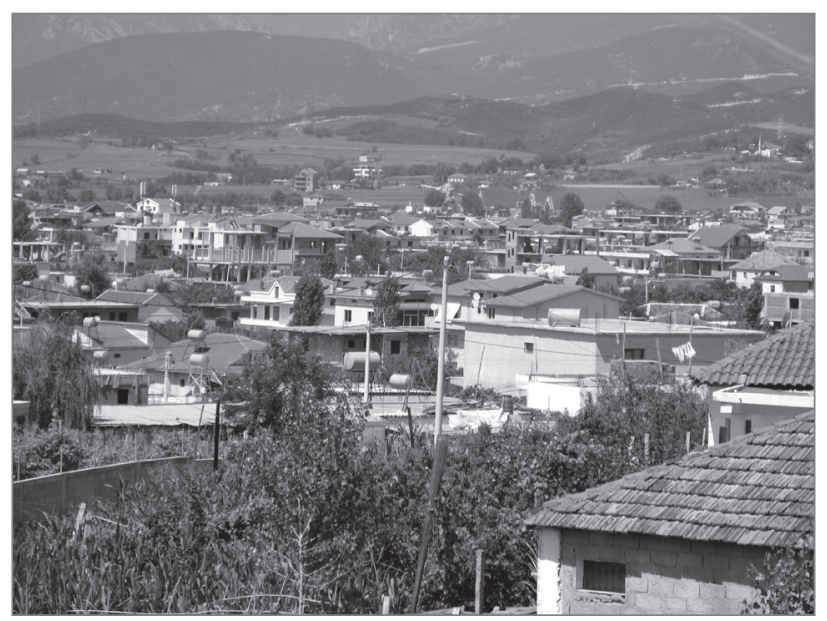

Slika 4: Nova neformalna naselja v Tirani (foto: Sasha Tsenkova) 
Preglednica 2: Dostop do infrastrukture v neformalnih naseljih v Tirani in Beogradu (\% bivališč)

\begin{tabular}{lccc}
\hline Infrastruktura & Neformalna naselja v Tirani & Tirana & Albanija \\
\hline kanalizacija & 46,0 & 91,0 & 58,0 \\
\hline vodovodno omrežje & 41,0 & 95,0 & 56,0 \\
\hline centralno ogrevanje & 0,0 & 2,0 & 2,0 \\
\hline električno omrežje & 68,0 & 97,3 & 86,5 \\
\hline Infrastruktura & Romska naselja v Beogradu & Beograd & $(1991)$ \\
\hline kanalizacija & $(2002)$ & 92,0 & 78,0 \\
\hline vodovod & 25,2 & 98,0 & 90,0 \\
\hline centralno ogrevanje & 47,1 & 49,0 & 28,0 \\
\hline kad ali tuš & $/$ & 96,0 & 80,0 \\
\hline
\end{tabular}

Vir: Ekonomska komisija Združenih narodov za Evropo (ang. United Nations Economic Commission for Europe, v nadaljevanju: UNECE), 2002; občina Tirana, 2004; UNECE, 2005; Tsenkova, 2005

- prebivalci brez urejene kanalizacije z nedovoljenimi izpusti povečujejo onesnaževanje lokalnih vodnih virov:

- smeti se odlagajo ob cestah ali v lokalnih rekah in jezerih; ponekod neformalna naselja povzročajo okoljska tveganja s tem, ko se gradijo v naravnih rezervatih in na zavarovanih območjih, na primer na obalnih območjih Hrvaške in Črne gore.

\section{Politične rešitve}

Dunajska deklaracija o nacionalni regionalni politiki in programih neformalnih naselij v Jugovzhodni Evropi to problematiko označuje za prednostno nalogo in države spodbuja $k$ oblikovanju pristopa za doseganje trajnostne legalizacije in izboljšanja neformalnih naselij. V njej se zagovarja dejstvo, da je treba v prihodnje razvoj neformalnih naselij nujno preprečevati s pomočjo trajnostnega urbanega upravljanja, načel dobrega upravljanja in vključujoče krepitve zmogljivosti (ministrska konferenca o neformalnih naseljih v Jugovzhodni Evropi, 2004).[2] Iskanje političnih rešitev pri obravnavi neformalnih naselij je seveda večplastno in zadeva več različnih vidikov. V državah Jugovzhodne Evrope je bilo upoštevanih že veliko različnih projektov in programov urbanega razvoja, vendar poteka njihovo izvajanje v odvisnosti od posameznega primera in zelo počasi. Med predlaganimi rešitvami so legalizacija in vključevanje v formalno urbanistično načrtovanje, ureditev in zagotovitev najosnovnejših socialnovarstvenih storitev (na primer šole in zdravniške ambulante) in tehnične infrastrukture (na primer varne ceste, javni promet, voda in kanalizacija) ter programe preselitve v socialna stanovanja. Čeprav te rešitve spadajo v okvir različnih politik, zahtevajo tudi veliko politične volje ter finančne zavezanosti državnih in lokalnih ustanov. Poudarek je na teh ukrepih:

1. legalizacija,

2. ureditev in izboljšave,

3. preselitev.

\subsection{Legalizacija}

Legalizacija neformalnih naselij v regiji še vedno poteka. Pri tem se poudarja vključitev trga neformalnih zemljišč in stanovanj $\mathrm{v}$ formalno ekonomijo in zagotovitev dostopa do lastninskih pravic prek lastništva zemljišč. Legalizacija temelji na prizadevanjih za zagotovitev javnih prihodkov in stabilizacijo velikih mestnih skupnosti s pomočjo socialnih programov in programov izboljšanja infrastrukture. $\mathrm{V}$ splošnem se odzivi na legalizacijo razlikujejo glede na posamezna območja, vrste neformalnih naselij, politične usmeritve vlade in pritiske vpletenih skupnosti. V nekaterih državah (Hrvaška, Črna gora in Bolgarija) se legalizacija izvaja kot sestavni del novih prizadevanj za pripravo zakonskih načrtov za urejanje razvoja na lokalni ravni. V drugih državah (Albanija in Srbija) legalizacijo neformalnih naselij ureja posebna zakonodaja, vendar je njeno izvajanje omejeno. Albanski legalizacijski zakon iz leta 2007 vsebuje posebne določbe o neformalnih naseljih revnih ljudi, čeprav kršijo obstoječo načrtovalsko in gradbeno zakonodajo. Druge države v regiji uporabljajo podobne strategije, vendar njihovo izvajanje napreduje zelo različno (glej ponazoritev 5).

Ponazoritev 5: Legalizacija neformalnih naselij $v$ Albaniji in na Hrvaškem

ALUIZNI je pristojna nacionalna agencija za legalizacijo in urbanizacijo nezakonitih gradenj in naselij v Albaniji. Njena naloga je priprava predlogov za odobritev legalizacije neformalnih naselij. ALUIZNI je pripravila pilotski legalizacijski postopek za območje, ki pokriva 55 hektarjev. Območje se trenutno podrobno pregleduje, saj želijo pridobiti popolno digitalizirano dokumentacijo z najmanj 30 lastnostmi za vsako zemljišče, ki naj bi se ga prijavilo. Prva legalizacijska dovoljenja so bila izdana februarja 2007. Temu postopku bo sledila prijava zemljišč, in sicer potem ko se plača davek v višini 1 USD/ $\mathrm{m}^{2}$. Skupno govorimo o 681 neformalnih območjih, od katerih je za 152 območij (23.000 hektarjev zemljišč) tehnična in pravna dokumentacija že pripravljena, za 281 pa se ta še zbira. Približno 98 območij (ali 168 hektarjev) zasedajo občinske stavbe; ta območja se ne štejejo za neformalna naselja. Skupno je ALUIZNI prejela približno 
350.000 prošenj za legalizacijo, med drugim približno 80.000 za večstanovanjske stavbe in trgovine (Aldoni, 2007). Problem neformalnih stanovanj na Hrvaškem je še posebej zapleten na obalnih območjih, kjer vodi do vzpostavitve neformalnih naselij. $V$ večini primerov gre za počitniške hišice ali komercialne gradnje, ki kršijo načrtovalske in gradbene predpise. Problem se je začel stopnjevati po letu 1995, ko so bili legalizacijski predpisi ukinjeni in se je povečala možnost priklopa na infrastrukturo. Na otoku Vir je bilo zgrajenih na primer 9.000 nezakonitih stavb in na obali Rogoznice še dodatnih 1.800 . Zgodovina neformalnih naselij na Hrvaškem sega v obdobje komunizma. Predpisi, sprejeti leta 1992, so dovoljevali legalizacijo vseh neformalnih stavb (takratno število je bilo ocenjeno na 100.000). V treh letih je bilo legaliziranih 35.000 stavb. Od leta 2003 je direktorat za inšpekcijske zadeve, ki deluje v okviru hrvaškega ministrstva za varstvo okolja in prostorsko načrtovanje, sprejel nekatere ukrepe za reševanje teh problemov. Skupno so porušili 1.600 neformalno zgrajenih stavb, 4.000 pa so jih legalizirali. Pred rušenjem se natančno preveri, ali je stavba naseljena in ali imajo stanovalci tudi druge nepremičnine. Legalizacija je vključena v načrtovalski postopek.

Vir: Tsenkova (2008)

\subsection{Ureditev in izboljšave}

Urejanje in izboljšanje neformalnih naselij je bolj zapleten poseg. Rešitve niso šablonske, preprosto zakonite ali nezakonite, formalne ali neformalne. Izbira legalizacije namesto ureditve je odvisna od politične volje pristojnih organov, lobiranja in pogajalskih zmožnosti stanovalcev ter lokacije, velikosti in kakovosti stanovanj v naselju.

Pri urejanju in izboljševanju je poudarjena pomembnost ukrepanja na treh ravneh: v soseski (ali neformalnem naselju), mestu in na metropolitanskem območju. Čeprav gre predvsem za načrtovalske ukrepe, postopek običajno vključuje tudi prijavo zemljišča in nepremičnine ter načrte za dostop do infrastrukture in socialnovarstvenih storitev. V več državah (Albanija, Srbija in Bolgarija) manjši pilotni projekti kažejo, da tak pristop prispeva k izboljšavam. Čeprav je učinkovitost takih projektov težko oceniti, zahtevajo sodelovanje stanovalcev, načrtovalcev, občine in osrednjih državnih organov. $\mathrm{Na}$ ravni soseske se na podlagi sodelovanja med načrtovalci, osnovnimi organizacijami skupnosti, družinami in posamezniki opredelijo neposredni problemi stanovalcev, da bi se poiskale mogoče rešitve. Na mestni ravni morajo načrtovalci in nosilci odločanja upoštevati dinamiko skupnosti in vpliv mogoče vključitve v mestno območje z vidika prometnih in infrastrukturnih zahtev, stroškov in okoljskih posledic. Na metropolitanski oziroma regionalni ravni je treba za dosego ozaveščenih političnih in načrtovalskih odločitev, ki bodo koristile mestu, upoštevati vplive in interakcije znotraj urbane aglomeracije, zlasti pri večjih neformalnih naseljih (Svetovna banka, 2001; Bolay, 2004). Taki strateški pristopi so pogosto del nove generacije glavnih načrtov in mestnih strategij v obravnavani regiji (na primer Tirana, Durres, Beograd in Skopje), vendar se v praksi le redko izvajajo.
Gradnja ter vzdrževanje infrastrukture in javnih dobrin pomenita velik korak naprej $\mathrm{k}$ formaliziranju in izboljšanju neformalnih naselij. Ko se ugotovi, da lahko neformalno naselje ostane na obstoječi lokaciji, je nujno oblikovanje partnerstev, ki pomagajo kriti stroške stanovanj in izboljšav. Pomembno je, da stanovalci sodelujejo v celotnem procesu ter da se jih spodbudi $\mathrm{k}$ plačevanju stroškov infrastrukture in javnih dobrin, $s$ čimer začnejo te storitve tudi ceniti. Poleg tega morajo vlade za reševanje problema pomanjkanja osnovne infrastrukture nameniti sredstva iz svojega proračuna. Dober primer takega pristopa je ureditev romskega naselja Gorica v Sarajevu, ki obsega približno 60 gospodinjstev. Družine so živele na parceli, ki je bila v delni lasti državnega podjetja in občine. Po vojni leta 1996 so razseljene družine svoje domove obnovile, čeprav je obstajala nevarnost, da jih bodo z območja prisilno izselili. Leta 2000 je združenje goriških stanovalcev zaprosilo več mednarodnih organizacij, med njimi OVSE, OHR in UNHCR, naj sprožijo postopek regularizacije, $s$ katerim bi spremenili namembnost zemljišč v stanovanjske namene, občina bi izplačala zemljiški delež lastniku (državnemu podjetju), lastništvo pa bi se preneslo na romske prebivalce. Obnova v Gorici se je začela spomladi 2002 pod okriljem krščanske humanitarne organizacije World Vision (OVSE, 2006).

\subsection{Preselitev}

Ena od mogočih rešitev vprašanja neformalnih naselij je tudi preselitev stanovalcev v socialna stanovanja ali neko drugo obliko subvencioniranega formalnega naselja. To je verjetno najdražja rešitev in ni presenetljivo, da je izvajanje te v praksi razmeroma omejeno. V večini primerov je preselitev namenjena revnim prebivalcem neformalnih naselij ali ranljivim skupinam, kot so Romi, begunci in notranje razseljene osebe. $\mathrm{Za}$ to težko nalogo preselitve velikih skupin revnih migrantov in beguncev ter njihove posledične vključitve v obstoječa mesta ni splošnega modela. Čeprav obstaja splošno prepričanje, da so učinkovite socialne politike in programi, ki zagotavljajo dostop do cenovno ugodnih in varnih stanovanj, izredno pomembni, si jih centralna in lokalna raven, zlasti v državah, ki jih prizadenejo vojne ali begunske krize, pogosto ne moreta privoščiti. Mnogo rešitev, povezanih s preselitvijo, se nanaša na manjše projekte, ki jih financirajo s pomočjo mednarodnih agencij ali z dvostransko pomočjo (slika 5).

Prispevki Razvojne banke Sveta Evrope za preselitev beguncev so bili večji. S pomočjo projektov, ki jih je financirala ta banka, so leta 2005 preselili več kot 2.300 ljudi v Bosni in Hercegovini, Srbiji in Črni gori, leta 2006 pa so v okviru podobnega projekta pomagali 1.081 nekdanjim stanovalcem zbirnih centrov v Srbiji in Črni gori. Podobne projekte je financirala tudi Evropska komisija s pomočjo nepovratnih sredstev, ki jih je namenila Bosni in Hercegovini v okviru svojega programa 


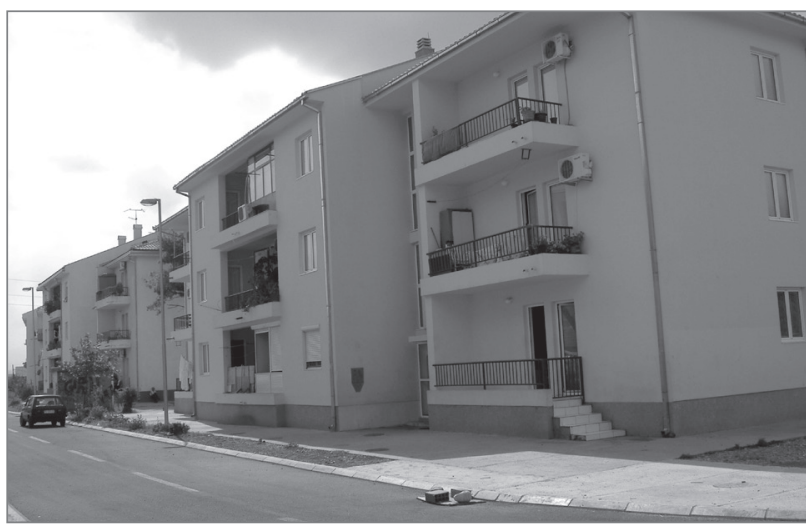

Slika 5: Socialna stanovanja za begunce in notranje razseljene osebe v Podgorici (foto: Sasha Tsenkova)

za vrnitev beguncev in razseljenih oseb. Evropska agencija za obnovo je pred kratkim namenila 2,4 milijona EUR gradnji cenovno dostopnih stanovanj za begunce in notranje razseljene osebe v Črni gori.

\section{Sklep: neformalna naselja kot problem in rešitev}

Upoštevanje ekonomskih, socialnih in okoljskih vprašanj, povezanih $\mathrm{z}$ neformalnimi naselji, je pomemben korak $\mathrm{k}$ oblikovanju različnih programov in praktičnih rešitev za obravnavo problemov. Ob hitri rasti neformalnih naselij in trdovratnosti »neformalnih mest « v večini držav Jugovzhodne Evrope so lokalne in nacionalne politike prepozno spoznale, da neučinkoviti stanovanjski sistemi ter sistemi načrtovanja in upravljanja z zemljišči stanje samo še poslabšajo. Zdaj obstaja splošno zavedanje, da priseljenci v mestih pogosto končajo kot nezakoniti prebivalci neformalnih naselij, saj si te skupine stanovanj in zemljiš̌̌ na formalnem trgu ne morejo privoščiti (Gabriel, 2007).

Državna pomoč, namenjena reševanju stanovanjske problematike revnih mestnih prebivalcev in socialno ogroženih skupin, se je v zadnjem desetletju zmanjšala, s čimer se je breme preložilo na lokalno raven, skupine znotraj skupnosti in posamezna gospodinjstva. Nezakoniti ali neformalni nakupi zemljišč so morda naravni mehanizem soočanja s težavami revnih priseljencev in beguncev, kar nakazujejo tudi hitro rastoča neformalna naselja na periurbanem območju Prištine (slika 6).

Država zdaj ponuja storitve in usklajuje politike in ukrepe na urbanem področju, vendar trg vsem družbenim slojem ne more ponuditi cenovno dostopnih in primernih stanovanj. Neformalna naselja so jasen pokazatelj tega prehoda v upravljanju. $\mathrm{V}$ najboljšem primeru je vse večja vloga države prispevala $\mathrm{k}$ izboljšanju zakonodaje, infrastrukture in storitev ter tudi $\mathrm{k}$ poskusom ureditve neformalnih naselij na ravni skupnosti, v

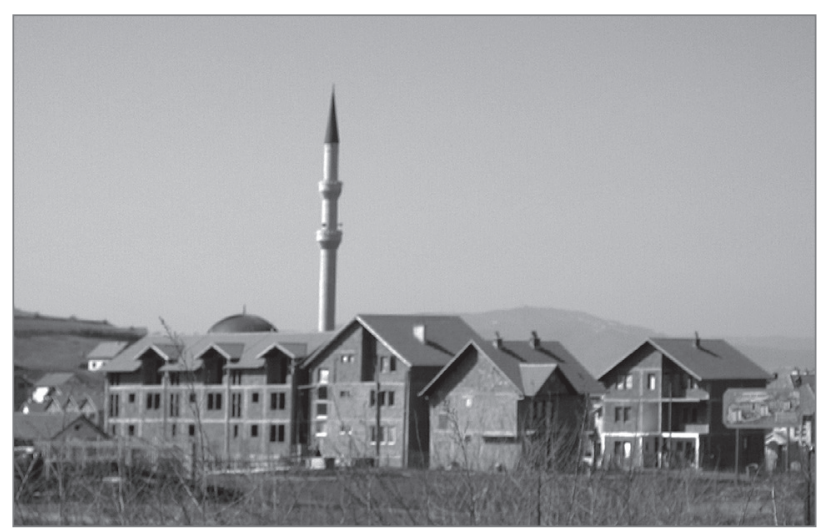

Slika 6: Hitra rast neformalnih naselij na periurbanem območju Prištine (foto: Sasha Tsenkova)

najslabšem primeru pa se država preprosto ni zmenila za rast neformalnih naselij, omejila je ponudbo zemljišč, spodbudila korupcijo in revne prisilila živeti v prostorsko in socialno izoliranih slumih. Problematiko neformalnih naselii, zlasti tistih, ki jih zgradijo revni mestni prebivalci, je zato treba razumeti v tem kontekstu. Krepi se zavest o tem, da bi neformalna naselja morda morali razumeti kot sprejemljivo » rešitev « $\mathrm{z}$ vidika socialnega odziva na neučinkovit sistem zagotavljanja stanovanj in zemljišč, čeprav ne moremo zanikati, da so problem z vidika urbanega upravljanja.

Drug problem je ta, da neformalnih naselij ne gradijo samo revni mestni prebivalci, ampak tudi zasebni investitorji in bogati posamezniki. Ni preveč verjetno, da se bo ta smer razvoja linearno spremenila. Nezakonita gradnja na mestnih območjih, ki je pogosto posledica pomanjkanja jasne načrtovalske ureditve ali izvajanja obstoječih načrtov, je v mnogih mestih (na primer Tirana, Podgorica, Beograd in Prišstina) povzročila resne probleme. Neustrezno upravljanje z nepremičninami in slabi zemljiškoknjižni sistemi položaj samo še poslabšujejo, saj dodatno poglabljajo težave urbanega upravljanja $s$ tem, ko ne zagotavljajo preglednega sistema lastništva zemljišč in lastninskih pravic. Rešitve problemov neformalnih stanovanj so najpomembnejše za dobro delovanje nepremičninskega trga in zaščito lastninskih pravic, zato se morajo države pri svojih pristopih osredotočiti na ranljive skupine in se izogibati široko zastavljenim politikam, ki lahko samo še spodbudijo razvoj neformalnih naselij.

Sasha Tsenkova

University of Calgary, Faculty of Environmental Design, Calgary, Kanada

E-pošta: tsenkova@ucalgary.ca

\section{Opombe}

${ }^{[1]} \mathrm{Na}$ območju Beograda na primer prirast na uradnem nepremičninskem trgu znaša 1.500 enot na leto, na črnem pa približno 50.000 enot na leto. 
[2] Albaniji, Bosni in Hercegovini, Hrvaški, Kosovu, Makedoniji, Črni gori in Srbiji krepitev zmogljivosti za izpolnjevanje zavez Dunajske deklaracije do neke mere zagotavljata Pakt stabilnosti in rasti in UNHABITAT v okviru programa krepitve regionalne usposobljenosti na področju razvoja mest in stanovanjske politike (ang. Regional Capacity Strengthening Programme for Urban Development and Housing, v nadaljevanju: RCSP).

\section{Zahvala}

Prvotna različica tega članka je bila objavljena v: Tsenkova, S. (2009): Housing reforms in post-socialist Europe: lost in transition. Heidelberg, Springer-Verlag. V članku so predstavljena le avtoričina mnenja, kar pomeni, da se ta ne smejo pripisovati agencijam, ki so to raziskavo finančno podprle (CEB in UNECE).

\section{Viri in literatura}

Aldoni, D. (2007): Legalization of informal settlements in Albania. Prispevek je bil predstavljen na konferenci z naslovom 5th Regional Vienna Declaration Review Meeting, Stability Pact for South Eastern Europe, ki je potekala od 22. do 23. oktobra na Dunaju v Avstriji. Tipkopis.

Beograjski urbanistični inštitut (2003a): Programme offering solutions for the issue of the unsafe settlements in Belgrade. Beograd.

Beograjski urbanistični inštitut (2003b): Generalni plan Beograda do 2021. Beograd.

Besnik, A., Lulo, K., in Myftiu, G. (2003): Tirana - sfida e zhvillimit urban. Tirana, CETIS

Bolay, J. C. (2006): Slums and urban development: Questions on society and globalisation. The European Journal of Development Research, 18(2), str. 284-298. DOI: 10.1080/09578810600709492

Center za spremljanje notranjega razseljevanja (2007): Global Monitoring Project. Dostopno na: http://www.internal-displacement.org (sneto 26. 10. 2007).

De Soto, H. (2003): The mystery of capital: Why capitalism triumphs in the West and fails elsewhere. New York, Basic Books.

Ekonomska komisija Združenih narodov za Evropo (2002): Country profiles on housing: Albania. Ženeva.

Ekonomska komisija Združenih narodov za Evropo (2005): Country profiles on housing: Serbia and Montenegro. Ženeva.

Gabriel, B. (2007): Informal settlements in SEE - A regional support approach. Prispevek je bil predstavljen na delavnici z naslovom Informal Settlements - Real Estate Markets Needs Related to Good Land Administration and Planning FIG Commission 3 Workshop, ki je potekala od 28. do 31. marca v Atenah v Grčiji. Tipkopis.

Leckie, S. (2002): Regional housing issues profile, implementing housing rights in south east Europe. Nairobi, UN-HABITAT.

Ministrska konferenca o neformalnih naseljih v Jugovzhodni Evropi (2004): Vienna declaration on informal settlements in south eastern Europe. Dostopno na: http://www.unhabitat.org.pl/files/300/vienna_declaration.pdf (sneto 10. 7. 2010).

Ministrstvo za človekove pravice in begunce (2004): Information on situation in the field of return of refugees from $\mathrm{BIH}$, displaced persons in $\mathrm{BIH}$ and returnees. Sarajevo.

Ministrstvo za kapitalske naložbe Državne skupnosti Srbije in Črne Gore (2004): The development of informal settlements in Belgrade. Prispevek je bil predstavljen na konferenci z naslovom Ministerial Conference on Informal Settlements in South Eastern Europe, ki je potekala od 28. septembra do 1. oktobra na Dunaju v Avstriji. Tipkopis.

Občina Tirana (2004): The development of informal settlements in Tirana. Prispevek je bil predstavljen na konferenci z naslovom Ministerial Conference on Informal Settlements in South Eastern Europe, ki je potekala od 28. septembra do 1. oktobra na Dunaju v Avstriji. Tipkopis.

Organizacija za varnost in sodelovanje v Evropi (2006): Report on Roma informal settlements in Bosnia and Herzegovina. Sarajevo.

Payne, G., in Majale, M. (2004): The urban housing manual: Making regulatory frameworks work for the poor. London, Earthscan.

Program Združenih narodov za naselja (2003): Global report on human settlements 2003: The challenge of slums. London.

Program Združenih narodov za naselja (2006): Four strategic themes for the housing policy in Serbia. Settlement and Integration of Refuge es Programme in Serbia (SIRP). Beograd.

Razvojna banka Sveta Evrope in Svetovna banka (2004): Housing in south eastern Europe: Solving the problem. Pariz.

Soaita, A. (2007): The new housing developments in Romania: Challenges and resident involvement. Prispevek je bil predstavljen na konferenci z naslovom European Network for Housing Research Conference, ki je potekala od 21. do 25. junija v Rotterdamu na Nizozemskem. Tipkopis.

Svetovna banka (2001): Upgrading urban communities: A resource framework. Washington, DC.

Svetovna banka (2007): World Bank responses to the problem of informal development: Current projects and future action. Prispevek je bil predstavljen na delavnici z naslovom Informal Settlements Real Estate Markets Needs Related to Good Land Administration and Planning FIG Commission 3 Workshop, ki je potekala od 28. do 31. marca v Atenah v Grčiji. Tipkopis.

Slaev, A. (2007): Bulgarian Policies towards the Roma Housing Problem and Roma Squatter Settlements. European Journal of Housing Policy, 7(1), str. 63-84. DOI: 10.1080/14616710601134753

Tsenkova, S. (2005): Trends and progress in housing reforms in south east Europe. Pariz, Razvojna banka Sveta Evrope.

Tsenkova, S. (2008): The challenge of informal settlements in the ECE region: A search for adequate policy responses. Ženeva, UNECE.

Tsenkova, S. (2009): Housing reforms in post-socialist Europe: Lost in transition. Heidelberg, Springer-Verlag. DOI: 10.1007/978-3-79082115-4

Vucksanovic, Z. (2007): Solutions to informal settlements. Prispevek je bil predstavljen na konferenci z naslovom 5th Regional Vienna Declaration Review Meeting, Stability Pact for South Eastern Europe, ki je potekala od 23. do 24. novembra v Podgorici v Črni gori. Tipkopis. 